This article was downloaded by: [University of Alberta]

On: 12 March 2015, At: 05: 48

Publisher: Routledge

Informa Ltd Registered in England and Wales Registered Number: 1072954

Registered office: Mortimer House, 37-41 Mortimer Street, London W1T

3J H, UK

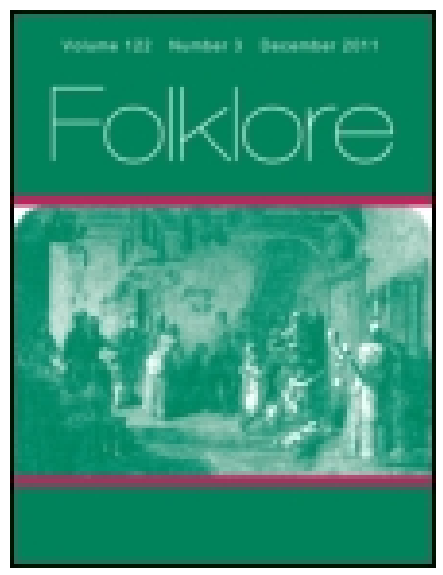

\title{
Folklore
}

Publication details, including instructions for authors and subscription information:

http:// www. tandfonline.com/loi/ rfol20

\section{The Six Simpletons and Other Stories}

J. D. Anderson

Published online: 01 Feb 2012.

To cite this article: J. D. Anderson (1920) The Six Simpletons and Other Stories, Folklore, 31:2, 144-144, DOI: 10.1080/0015587X.1920.9719138

To link to this article: http:// dx. doi. org/ 10.1080/0015587X.1920.9719138

\section{PLEASE SCROLL DOWN FOR ARTICLE}

Taylor \& Francis makes every effort to ensure the accuracy of all the information (the "Content") contained in the publications on our platform. However, Taylor \& Francis, our agents, and our licensors make no representations or warranties whatsoever as to the accuracy, completeness, or suitability for any purpose of the Content. Any opinions and views expressed in this publication are the opinions and views of the authors, and are not the views of or endorsed by Taylor \& Francis. The accuracy of the Content should not be relied upon and should be independently verified with primary sources of information. Taylor and Francis shall not be liable for any losses, actions, claims, proceedings, demands, costs, expenses, damages, and other liabilities whatsoever or howsoever caused arising directly or indirectly in connection with, in relation to or arising out of the use of the Content.

This article may be used for research, teaching, and private study purposes. Any substantial or systematic reproduction, redistribution, reselling, loan, sub-licensing, systematic supply, or distribution in any form to anyone is 
expressly forbidden. Terms $\&$ Conditions of access and use can be found at http://www.tandfonline.com/page/terms-and-conditions 
mess would naturally eject it at once. The whole of the pot was emptied out and Elisha was obliged to provide from his secret hoard a mess of porridge.

The so-called miraculous draught of fishes is not in my opinion described in such a way as to suggest a miracle at all, but rather to illustrate the interest that Christ took in the daily pursuits of his followers. In the Lake of Tiberias certain fish collected in large numbers before the breeding season round the mouth of small streams. Their shoals can be seen by a man walking on the shore of the lake, which is at many places shelving, much more easily than by people in a boat.

Nelson annandale.

The Six Simpletons and Other Stories.

(Folk-lore, vol. xxxi. p. 77.)

Sir George Grierson's note on the travels of "The Prince that Didn't Exist," reminds me of another familiar tale found in regions far distant from one another. Miss Sitä Devi has recently published, in the Bengali language, a delightful little volume of folk-tales entitled Niret Gurur Kahini, composed chiefly of the misfortunes which befel a simpleton Brähman called Niret and his five disciples, as silly as hinself, known by the significant names of Akăt, Hảba, Hãā, Bokã and Ahmak. This legend Miss Sita has borrowed from The Adventures of the Gooroo Noodle, by Benjamin Barrington, I.C.S., itself copied from the eighteenth century version of the Rev. P. Vesci, in the Tamil language, published under the title of Guru Para* marttan. Now it happens that about 1886 I was told this same story in the Boḑo or Kachãri language in Assam by a Kachări friend of mine called Samson, with some variations. No doubt the story is found all over India, but that it should be common to Hindu Trichinopoli and to the non-Hindu Kachari dwears is surprising.

J. D. Andergon. 